Saudi Journal of Biomedical Research

Abbreviated Key Title: Saudi J Biomed Res ISSN 2518-3214 (Print) |ISSN 2518-3222 (Online)

\title{
Effects of Quarry Dust on Some Haematological Parameters among Workers at Okposi Umuoghara, Ebonyi State - Nigeria
}

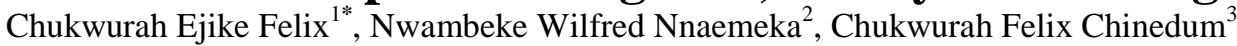 \\ ${ }^{1}$ Haematology \& Immunology Unit, Dept. of Medical Laboratory Sciences, Faculty of Health Sciences \& Technology, Ebonyi State University, \\ Abakaliki, Nigeria \\ ${ }^{2}$ Department of Medical Laboratory Sciences, Faculty of Health Sciences \& Technology, Ebonyi State University, Abakaliki, Nigeria \\ ${ }^{3}$ Shenyang Medical College, Shenyang Liaoning P.R. China/Dept of Surgery, Enugu State University Teaching Hospital, Enugu, Nigeria
}

DOI: $10.36348 /$ sjbr.2020.v05i05.003

| Received: 01.05.2020 | Accepted: 08.05.2020 | Published: 12.05.2020

*Corresponding author: Chukwurah Ejike Felix

\section{Abstract}

Background: Unregulated mining has the potential to release harmful substances into the soil, air, and water and this may be associated with negative health, social and environmental impacts. Inhalable dust is produced during processing, grading and during the transit by the vehicles. Epidemiologic data indicate that there are occupational hazards associated with stone crushing and inhalation of stone dust. Quarrying/stone crushing is increasingly becoming the main stay of Ebonyi State economy and major source of internally generated revenue yet there is little or no government policy on regulation and occupational safety. Aim: This study examined the effect of long time exposure to quarry dust on the Full Blood Count (FBC) of quarry workers at Okposi Umuoghara, Ezza LGA of Ebonyi State - Nigeria. Methods: Crosssectional, descriptive and analytical study was carried out on 100 quarry workers; 36 males and 54 females (age; between 18-57 years) who were exposed to stone dust for more than one year and 84 age/sex matched workers not exposed to quarry dust as control. The haemoglobin concentration, haematocrit, total while blood cell and differential counts were estimated using standard methods. Results: Majority of the quarry workers in Okposi - Umuoghara Idustrial Estate were female, low income and uneducated who are not aware of the health implications of their carrier. There were significant differences in mean values of in $\mathrm{Hb}, \mathrm{PCV}$, and total $\mathrm{WBC}$, relative netrophils, lymphocytes and eosinophil counts compared with control. The differential lymphocytes and eosinophil increased significantly $(\mathrm{p}>0.05)$, while the $\mathrm{Hb}$, $\mathrm{PCV}$, total WBC and relative neutrophil count decreased significantly $(\mathrm{P}<0.05)$. No significant variation in differential monocyte count was observed. Conclusion: The alterations in level of some haemotological parameters in exposed workers is an indication of effect of quarry dust on pathopysiology of blood and reticuloendothelia system of factory workers and in general human health. There is need for regular health evaluation of workers and education on the essential safety precautions through the use of personal protective equipment and more mechanized and safer means of stone processing.

Keywords: Occupational exposure, Quarry dusts, Haematological parameters, safety.

Copyright @ 2020: This is an open-access article distributed under the terms of the Creative Commons Attribution license which permits unrestricted use, distribution, and reproduction in any medium for non-commercial use (NonCommercial, or CC-BY-NC) provided the original author and source are credited.

\section{INTRODUCTION}

The health and social impacts of working in stone quarrying and related mining industries have been well documented. Inhalable dust is produced during processing, grading and during the transit by the vehicles. Epidemiologic data indicate that there are occupational hazards associated with stone crushing and inhalation of stone dust [1-3]. A particular concern in some quarries is the inhalation of dust containing silica which can lead to silicosis [4-5]. Studies indicate that workers exposed to quarry dusts have increased risk of developing lung cancer, pulmonary tuberculosis and airway diseases [6-7]. Respiratory problems and occupational lung diseases are the major health hazards in dust-exposed workers and major cause of morbidity and mortality all over the world [8-11].

The progress of stone quarry industry in Abakaliki - Nigeria has increased from manual to semiautomated method year to year, largely owned by private business men with little or no government assistance. Apart from agriculture it is the major drive of the economy through the internally generated revenue. In the workplaces in developing countries health hazard and safety issues get less attention and such laborers are often exposed to dust without being aware of its threat to their health. There is need 
therefore for initiatives to reduce risk and maximize benefits for occupational health and environmental safety.

To reduce the occupational risks associated with stone crushing, the workers should be educated on safety through the use of personal protective equipment (PPE), air purifying respirator (non power type)s and use a wet method on mining activities. Proper regulation and monitoring should be instituted to evaluate the health and safety of workers. Medical evaluation of the workers should be regularly and routinely done for timely and early detection of health related issues. This may be achieved by routine clinical and laboratory assessments like the full blood count [12]. These measures are however not well articulated in developing countries and indeed Nigeria.

Full blood count (FBC) which measures several components and features of blood is used to evaluate overall health and detect wide range of disorders, including anemia, infection and malignancies. Abnormal increases or decreases in cell counts as revealed in a full blood count may indicate an underlying medical condition that calls for further evaluation. Previous studies indicate that FBC have clinical utility in diagnosis and as biomarker associated with severity of diseases [12, 13-15]. This study therefore examined the full blood count (haemoglobin concentration, total white blood cell count and differential) among quarry workers exposed to quarry dust at Okposi Umughara industrial Layout, Ebonyi State Nigeria. This could possibly serve as evidencebased study that may be useful in health, environment and safety policy formulation towards occupation safety and environmental protection.

\section{METHODS}

\section{Subjects and Sampling}

This cross-sectional, descriptive and analytical study was conducted at Quarry Industrial layout, Okposi Umuoghara, Ezza North LGA of Ebonyi State Nigeria. Only workers involved in crushing, clearing and loading of quarry products and constantly exposed to quarry dust were sampled for full blood count (haemoglobin concentration, haematocrit, total white blood cell and differential counts). Written informed consent was obtained from each participant and study protocol was approved by Ebonyi State University Ethical Review Committee. Strict anonymity was observed throughout the study and intervention programmed aimed at educating the quarry workers on the safety and health implications of their work instituted. Sample size was calculated using the method of Cochran [16].

A total of 184 individuals comprised of 100 quarry workers (male, 36; female 64) between $18-57$ years and 84 age/sex-matched manual workers not exposed to quarry dust as control population were sampled between September to December 2019. Quarry workers with less than one year experience were excluded. Three milliliters of blood was collected from each participant into EDTA bottle for the assay and done without storage.

\section{Measurements of Variables}

The $\mathrm{Hb}, \mathrm{PCV}$, total $\mathrm{WBC}$ and differentials were done without preservation using standard methods. Data were analyzed using Pearson correlation and Student T-test, adapted from Statistical Package for Social Sciences (SPSS) version 22 and Microsoft excel software. Statistical significance was set at $\mathrm{p}<0.05$. Volunteer's age, contact details and analysis were stored in a password protected computer. During processing and analysis all samples were recognized by the laboratory number without any detail of the volunteer, each volunteers result were communicated to him/her only.

\section{RESULT}

There are 68 stone crushing plants at Quarry Industrial Layout Okpossi Umuoghara, Ebonyi State Nigeria. About 1250 workers are daily engaged in plants stone processing and transportation. The machines are mainly operated by men while the majority of females are engaged in grading and sorting of products. All the workers work for 9hours daily between $8 \mathrm{am}$ and $5 \mathrm{pm}$ except on Sundays.

The mean $( \pm \mathrm{SD})$ values of haematological parameters (PCV, Hb, TWBC and WBC differentials) of quarry workers exposed to quarry dust and compared with control are presented in Table-1. There were significant differences in mean values of in $\mathrm{Hb}, \mathrm{PCV}$, and total WBC, relative netrophils, lymphocytes and eosinophil counts compared with control. The differential lymphocytes and eosinophil increased significantly $(\mathrm{p}>0.05)$, while the $\mathrm{Hb}, \mathrm{PCV}$, total WBC and relative neutrophil count decreased significantly. No signifificant variation in differential monocyte count was observed. 
Table-1: Comparison of Mean values $( \pm \mathrm{SD})$ of $\mathrm{Hb}, \mathrm{PCV}$, total $\mathrm{WBC}$ and $\mathrm{WBC}$ differentials of quarry workers and control

\begin{tabular}{|l|l|l|l|l|}
\hline Variables & QW $(\mathbf{n = 1 0 0})$ & Controls $(\mathbf{n}=\mathbf{8 4})$ & T- value & p-value $^{\mathbf{a}}$ \\
\hline PCV $(\%)$ & $40.52 \pm 2.43$ & $43.70 \pm 2.25$ & -6.632 & 0.000 \\
\hline Hb $(\mathrm{g} / \mathrm{dL})$ & $13.20 \pm 0.76$ & $14.85 \pm 0.88$ & -10.269 & 0.000 \\
\hline Total WBC(\%10 $/ \mathrm{L})$ & $4.50 \pm 0.86$ & $6.00 \pm 1.09$ & -7.260 & 0.000 \\
\hline Neutrophil (\%) & $46.56 \pm 10.24$ & $65.06 \pm 9.85$ & -9.205 & 0.000 \\
\hline Lymphocytes (\%) & $50.18 \pm 8.17$ & $34.04 \pm 10.03$ & 8.820 & 0.000 \\
\hline Monocytes (\%) & $0.68 \pm 1.186$ & $0.62 \pm 0.88$ & 0.288 & 0.774 \\
\hline Eosinophils (\%) & $2.38 \pm 3.85$ & $0.62 \pm 0.90$ & 3.149 & 0.003 \\
\hline
\end{tabular}

Key: QW - Quarry workers, Hb - Haemoglobin, PCV - Pack Cell Volume, WBC - White Blood Cell

\section{DISCUSSION}

Abakaliki, Ebonyi State Nigeria is endowed with abundant mineral resources which have contributed immensely to national wealth. With associated socio-economic benefits, mineral resources are important source of wealth for a nation but before they are harnessed, they have to pass through the stages of exploration, mining and processing $[17,18]$. In line of processing, stone dust are inhaled by workers leading to health and social impacts to workers and environment. Occupational exposure to quarry dust and health implications in Nigeria have be documented [1921] with paucity of information as it effects on haematological parameters.

Full blood count is a nonspecific test that indirectly measures which measures several components and features of blood and used to evaluate overall health and detect wide range of disorders, including anemia, infection and malignancies. Clinical utilities have been documented in chronic and acute inflammation due to trauma, injury and infection as well as in autoimmune diseases, allergy and cancers [22-24].

In the present study, the $\mathrm{Hb}$ and $\mathrm{PCV}$ decreased significantly when compared with control. This indicates anaemia which may be due to intrinsic or extrinsic factors. This is in parity with the findings of Emmanuel et al., [21] in cement factory in the same environment. The works of other researchers support these findings [25, 26]. The higher incidence of respiratory infections [27] and aggravated inflammatory responses observed in quarry workers may be attributable to the presence of higher level of respiratory system irritants in the quarry sites. This could possibly effect early-induce non-adaptive responses that may suppress the bone marrow or interfere with the haemopoietic process.

The reason for the significant decrease in total WBC count found in this study could not be explained. It differs from the work of Emmanuel et al., in similar exposure in same environment. Though the relative lymphocyte and eosinophils were high, this could not possibly relate to decrease in total WBC especially as there was significant increase in neutrophils. Eosinophilia observed in this study is expected mindful of irritation and allergic responses caused by the inhalation of quarry dust. Raised level of eosinophils has been associated with allergic responses [28] and significantly higher number of eosinophils has been reported in patients positive for nerve growth factor which plays an important role in allergies and respiratory diseases [29].

Significant increase in lymphocyte count was observed in this study similar to other finding [25, 30]. Altered immune responses in workers exposed to quarry dusts may contribute to the relative lymphocytosis.

It has been suggested that long duration of exposure to quarry dust might bring out significant haematological changes $[31,32]$ since various occupational exposures cause lung injury and initiate a chronic inflammatory process that may progress to initiate fibrosis. Alternatively, chronic exposure to irritating material might lead to adaptation process, which resists inflammation and leukocytosis. It has been suggested that adaptation process possibly may be responsible for the non significant rise in total WBC count with regard to the period of exposure [33].

\section{CONCLUSION}

In conclusion therefore, the alteration in level of haemotological parameters in exposed workers is an indication of effect of quarry dust on pathopysiology of blood and reticuloendothelia system of factory workers and in general human health. There is need for regular health evaluation of workers and education on the essential safety precautions through the use of personal protective equipment and more mechanized and safer means of stone processing.

\section{REFERENCES}

1. Nwibo, A. N., Ugwuja, E. I., Nwambeke, N. O., Emelumadu, O. F., \& Ogbonnaya, L. U. (2012). Pulmonary Problems among Quarry Workers of Stone Crushing Industrial Site at Umuoghara, Ebonyi State, Nigeria. Int Journal Occup Environ Med, 3(4):178-85.

2. Egwuonwu, V. A., Abidemi, T. B., Aiyejunsunle, C. B., Ezeukwu, O. A., Auwal, A., \& Okoye, C. E. (2013). A cross-sectional survey of work related 
musculoskeletal disorders prevalence and associated risk factors among quarry workers in a South Eastern Nigerian community. The Internet Journal of Epidemiology, 11(2): 1-7.

3. WS, E. S., MG, M., \& GH, E. S. (2018). Impact of dust exposure among stone quarry workers on ventilatory functions and serum level of tumour necrosis factor-alpha (TNF- $\alpha)$. Egyptian Journal of Occupational Medicine, 42(3), 443-452.

4. Gan, W. Q., Man, S. F. P., Senthilselvan, A., \& Sin, D. D. (2004). Association between chronic obstructive pulmonary disease and systemic inflammation: a systematic review and a metaanalysis. Thorax, 59(7), 574-580.

5. Isara, A. R., Adam, V. Y., Aigbokhaode, A. Q., \& Alenoghena, I. O. (2016). Respiratory symptoms and ventilatory functions among quarry workers in Edo state, Nigeria. Pan African Medical Journal, 23(1); 212.

6. National Institute for Occupational Safety and Health (NIOSH). (2003). Work-Related Lung Disease Surveillance Report 2002. Publication No. 2003-111; Cincinnati, OH: National Institute for Occupational Safety and Health.

7. Ezeonu, F. C., \& Ezejiofor, T. I. N. (1999). Biochemical indicators of occupational health hazards in Nkalagu cement industry workers, Nigeria. Science of the total environment, 228(23), 275-278.

8. World Health Organization. (2006). Elimination of Asbestos-Related Diseases. Geneva, Switzerland: World Health Organization; [Accesed Online; Mar 28, 2020].

9. World Health Organization. (2010). Hazard Prevention and Control in the Work Environment: Airborne Dust; www.who.int/occupational_health/publications/en/ oehairbornedust.pdf. [Accesed Online; Mar 28, 2020].

10. Rom, W. N., \& Markowitz, S, eds. (2007). Environmental and Occupational Medicine. 4th ed. Philadelphia, PA: Lippincott Williams \& Wilkins. 237-245.

11. Walter, R. E., Wilk, J. B., Larson, M. G., Vasan, R. S., Keaney Jr, J. F., Lipinska, I., ... \& Benjamin, E. J. (2008). Systemic inflammation and COPD: the Framingham heart study. Chest, 133(1), 19-25.

12. Felix, C. E., Ogodo, N. D., \& Ngozi, A. A. (2003). Evaluation of body mass index, hematocrit, erythrocyte sedimentation rate and total protein in voluntary and commercial blood donors in Nigeria: Advocating for simultaneous screening for nutritional status. Int $J$ Blood Transfus Immunohematol, 7, 26-32.

13. Singh, D., Edwards, L., Tal-Singer, R., \& Rennard, S. (2010). Sputum neutrophils as a biomarker in COPD: findings from the ECLIPSE study. Respiratory research, 11(1), 77-79.

14. Dickens, J. A., Miller, B. E., Edwards, L. D., Silverman, E. K., Lomas, D. A., Tal-Singer, R., \&
Evaluation of COPD Longitudinally to Identify Surrogate Endpoints (ECLIPSE) study investigators. (2011). COPD association and repeatability of blood biomarkers in the ECLIPSE cohort. Respiratory research, 12(1), 146-151.

15. Koo, H. K., Kang, H. K., Song, P., Park, H. K., Lee, S. S., \& Jung, H. (2017). Systemic white blood cell count as a biomarker associated with severity of chronic obstructive lung disease. Tuberculosis and respiratory diseases, 80(3), 304-310.

16. Cochran, W. G. (1997). Sampling techniques ( $3^{\text {rd }}$ ed). New York: John Wiley \& sons.

17. Ajakaiye, D. E. (1995). Environmental problems associated with Mineral Exploitation in Nigeria, A paper presented at the 21 Annual Conference in the Nigeria Mining and Geoscience Society held at Jos, 140-148.

18. Adekoya, J. A. (2003). Environmental effect of Solid Mineral Mining. International Journal of Phvsical Science, 2: 625-640.

19. Aliyu, A. A., \& Shehu, A. U. (2007). Occupational hazards and safety measures among stone quarry workers in Northern Nigeria. Nigerian Medical Practitioner, 50(2), 42-47.

20. Ugbogu, O. C., Ohakwe, J., \& Foltescu, V. (2009). Occurrence of respiratory and skin problems among manual stone-quarrying workers. African Journal of Respiratory Medicine, 2009, 23-26.

21. Emmanuel, T. F., Ibiam, U. A., Okaka, A. N., \& Alabi, O. J. (2015). Effects of cement dust on the hematological parameters in Obajana cement factory workers. Eur Sci J, 11(27), 256-66.

22. Liaqat, I., Arshad, M., Arshad, R., \& Arshad, N. (2009). Exposure to Textile Chemicals Leads to Microcytic Anemia and Hypersensitivity in Textile Workers. Pakistan Journal of Zoology, 41(5):381 387.

23. Al-Mendalawi, M. D. (2011). Extremely elevated erythrocyte sedimentation rate. Etiology at a tertiary care center in Saudi Arabia. Saudi medical journal, 32(5), 536.

24. Swami, A., Chopra, V. P., \& Malik, S. L. (1994). Occupational Health Hazards in Stone Quarry Workers: A Multivariate Approach. Journal of Human Ecology, 5(2), 97-103.

25. Jude, A. C., Sasikala, K., Kumar, R. A., Sudha, S., \& Raichel, J. (2002). Haematological and cytogenetic studies in workers occupationally exposed to cement dust. International Journal of human genetics, 2(2), 95-99.

26. Kumar, P., Gupta, Y. C., Tiwari, V., Tiwari, S., \& Singh, A. (2005). Haematological and biochemical abnormalities in Cirrhinus mrigala (Ham.) induced by lead. Journal of Ecophysiology and Occupational Health, 5(3/4), 213.

27. Maduka, S. O., Osim, E. E., \& Dimkpa, U. (2014). Respiratory symptoms and blood eosinophil level in workers exposed to quarry dust in South- 
Eastern Nigeria. J Environ Occup Sci, AprJun, 3(2), 1-6.

28. Gleich, G. J. (2000). Mechanisms of eosinophilassociated inflammation. Journal of Allergy and Clinical Immunology, 105(4), 651-663.

29. El-Banna, S. M. S., Mahdi, W. K. M., Ali, B. A. E., \& Raouf, M. M. (2006). Role of nerve growth factor in allergic and inflammatory lung diseases. JOURNAL OF MICROBIOLOGY IMMUNOLOGY AND INFECTION,39(6), 4445186.

30. Tulinska, J., Jahnova, E., Dusinska, M., Kuricova, M., Liskova, A., Ilavska, S., ... \& Harrington, V. (2004). Immunomodulatory effects of mineral fibres in occupationally exposed workers. Mutation Research/Fundamental and Molecular Mechanisms of Mutagenesis, 553(1-2), 111-124.
31. Redlich, C. A. (1996). Pulmonary fibrosis and interstitial lung diseases in occupational and environmental respiratory disease. Edited by Philip, Harber, Marc, B. Schenker and John, R. Balmes, Mosby London, 216, 286.

32. Guguloth, M. R., Sambanaik, A., \& Mude, J. (2012). The Effect of Cement Dust Exposure on Haematological Parameters of Cement Factory workers in Nalagonda, Andhra Pradesh. International Journal of Advancements in Research \& Technology, 1(5), 46-52.

33. Gholami, A., Tajik, R., Atif, K., Zarei, A. A., Abbaspour, S., Teimori-Boghsani, G., \& Attar, M. (2020). Respiratory Symptoms and Diminished Lung Functions Associated with Occupational Dust Exposure Among Iron Ore Mine Workers in Iran. The Open Respiratory Medicine Journal, 14(1):1-7. 